\title{
The $P h-3$ gene from Solanum pimpinellifolium encodes CC-NBS-LRR protein conferring resistance to Phytophthora infestans
}

\author{
Chunzhi Zhang • Lei Liu • Xiaoxuan Wang • Jack Vossen • Guangcun Li • Tao Li • \\ Zheng Zheng $\cdot$ Jianchang Gao $\cdot$ Yanmei Guo $\cdot$ Richard G. F. Visser $\cdot$ Junming Li $\cdot$ \\ Yuling Bai $\cdot$ Yongchen Du
}

Received: 13 November 2013 / Accepted: 24 March 2014 / Published online: 23 April 2014

(C) The Author(s) 2014. This article is published with open access at Springerlink.com

\begin{abstract}
Key message $P h-3$ is the first cloned tomato gene for resistance to late blight and encodes a CC-NBS-LRR protein.

Abstract Late blight, caused by Phytophthora infestans, is one of the most destructive diseases in tomato. The resistance $(R)$ gene $P h$-3, derived from Solanum pimpinellifolium L3708, provides resistance to multiple P. infestans isolates and has been widely used in tomato breeding programmes. In our previous study, $P h-3$ was mapped into a region harbouring $R$ gene analogues (RGA) at the distal
\end{abstract}

Communicated by C. Gebhardt.

C. Zhang and L. Liu contributed equally to this work.

Electronic supplementary material The online version of this article (doi:10.1007/s00122-014-2303-1) contains supplementary material, which is available to authorized users.

C. Zhang $\cdot$ L. Liu $\cdot$ X. Wang $\cdot$ T. Li $\cdot$ Z. Zheng $\cdot$ J. Gao $\cdot$ Y. Guo $\cdot$ J. Li $(\square) \cdot$ Y. Du $(\square)$

The Institute of Vegetables and Flowers, Chinese Academy of Agricultural Sciences, Zhongguancunnandajie 12,

100081 Beijing, People's Republic of China

e-mail: lijunming@caas.cn

Y. Du

e-mail: duyongchen@caas.cn

J. Vossen · R. G. F. Visser · Y. Bai ( $₫)$

Wageningen UR Plant Breeding, Wageningen University

and Research Center, Droevendaalsesteeg 1,

6708 PB Wageningen, The Netherlands

e-mail: bai.yuling@wur.nl

G. Li

Institute ofVegetables and Flowers, Shandong Academy of Agricultural Sciences, 250100 Jinan,

People's Republic of China part of long arm of chromosome 9. To further narrow down the $P h-3$ interval, more recombinants were identified using the flanking markers G2-4 and M8-2, which defined the $P h$ 3 gene to a $26 \mathrm{~kb}$ region according to the Heinz1706 reference genome. To clone the $P h-3$ gene, a bacterial artificial chromosome (BAC) library was constructed using L3708 and one BAC clone B25E21 containing the $P h-3$ region was identified. The sequence of the BAC clone B25E21 showed that only one RGA was present in the target region. A subsequent complementation analysis demonstrated that this RGA, encoding a CC-NBS-LRR protein, was able to complement the susceptible phenotype in cultivar Moneymaker. Thus this RGA was considered the $P h-3$ gene. The predicted $\mathrm{Ph}-3$ protein shares high amino acid identity with the chromosome-9-derived potato resistance proteins against $P$. infestans (Rpi proteins).

\section{Introduction}

Late blight, caused by Phytophthora infestans, is one of the most devastating diseases for field-grown tomatoes. Under favourable conditions, $P$. infestans can spread at an alarming pace, and the compatible host will be devastated within 7-10 days (Fry 2008). Fungicide treatment is currently the most common method to control late blight. However, fungicide application is costly and has a negative impact on human health and environmental safety. Moreover, the pathogen quickly evolves and some of the new variants are insensitive to commonly used fungicides (Goodwin et al. 1996). The disease is especially problematic for organic growers who do not use any chemical pesticides in the production process. Therefore, introduction of resistances from wild tomato species into cultivated tomato is considered as a valuable method to achieve durable late blight resistance. 
Currently, more than 60 Solanum resistance genes against $P$. infestans (Rpi genes), mainly in potato, have been located in 16 regions on 10 chromosomes (Rodewald and Trognitz 2013). Among them, some have been cloned through map-based cloning or allele mining (Rodewald and Trognitz 2013). Additional information on characterization of these cloned Rpi genes in potato can be found in numerous recent reviews related to this topic (Foolad et al. 2008; Hein et al. 2009; Vleeshouwers et al. 2011; Nowicki et al. 2012; Rodewald and Trognitz 2013). Most of the Rpi genes are identified in wild potatoes, such as $S$. demissum, $S$. bulbocastanum, S. venturii, etc. (Vleeshouwers et al. 2011; Rodewald and Trognitz 2013). In tomato, much less studies on late blight resistance have been carried out. This is in part because this pathogen in tomato was not as prevalent as in potato, at least before the 1990s when many of the potato isolates were not pathogenic to tomato (Nowicki et al. 2012). However, tomato P. infestans isolates have recently undergone significant genetic changes and are becoming one of the most devastating pathogens for tomato cultivation (Foolad et al. 2008).

$P$. infestans is heterothallic, and both A1 and A2 mating types are required for completion of the sexual cycle. Sexual reproduction results in high levels of genetic variation in the offspring and may lead to rapid pathogen evolution and thus increases the risk of epidemics (Foolad et al. 2008). In the latest reports, tomato $P$. infestans isolates collected in China and Tunisia are still A1 mating types (Guo et al. 2010; $\mathrm{Li}$ et al. 2013; Harbaoui et al. 2013). In the USA, however, the predominant clonal lineage US-22 in Wisconsin is A2 mating type and resulted in the epidemics on tomato in 2009 (Gevens and Seidl 2013). The A2 mating type of tomato $P$. infestans isolates has also been reported in Russia (Statsyuk et al. 2010). In South-West India, appearance of the (blue) 13_A2 lineage caused severe outbreaks of late blight on tomatoes from 2009 to 2010 (Chowdappa et al. 2013). In potato cultivation, the aggressive 13_A2 lineage has emerged in Northwest Europe and rapidly replaced other genotypes (Cooke et al. 2012). This lineage is also present in the population of potato $P$. infestans in China (Li et al. 2013), but has not been collected yet in the Chinese tomato $P$. infestans population.

Due to the recent increased significance of tomato late blight, more effort is needed to identify genetic resources for late blight resistance and transfer the resistance to breeding lines and cultivars. To date, resistance to $P$. infestans has been reported in wild tomato species. The $P h-1$ gene is the first reported Rpi gene in tomato, which is a dominant gene mapped on chromosome 7 and provides resistance against $P$. infestans isolate $\mathrm{T}_{0}$. The $P h-1$ gene was originally identified in Solanum pimpinellifolium accessions known as West Virginia 19 and 731 and has been introduced into the cultivated tomato (Bonde and Murphy
1952; Gallegly and Marvel 1955; Rich et al. 1962; Peirce 1971). The second Rpi gene $P h-2$ was identified in another S. pimpinellifolium accession (West Virginia 700) (Gallegly and Marvel 1955). The $P h-2$ gene, conferring incomplete late blight resistance, was mapped into an 8.4-cM interval on the long arm of chromosome 10 (Moreau et al. 1998). This gene provides partial resistance resulting in only a reduction in the rate of disease development (Goodwin et al. 1995; Black et al. 1996a). Resistance conferred by both $P h-1$ and $P h-2$ was overcome by different $P$. infestans isolates from China, Indonesia, Nepal and The Philippines (AVRDC 1995, 1998, 1999), which prompted further screening of tomato germplasm for new Rpi genes. As a result, S. pimpinellifolium L3708 was found to be highly resistant to a wide range of $P$. infestans isolates overcoming $P h-1$ and $P h-2$ (Black et al. 1996a, b). The late blight resistance in $\mathrm{L} 3708$ is conditioned by a partially dominant gene, $P h-3$, which was mapped on the long arm of chromosome 9 (Black et al. 1996a; Chunwongse et al. 2002; Zhang et al. 2013). With marker-assisted selection (MAS) using $P h$-3-linked molecular markers, this gene has been successfully introgressed into tomato breeding lines and tomato cultivars for both commercial processing and freshmarket (Foolad et al. 2008; Gardner and Panthee 2010a, b; Panthee and Gardner 2010; Robbins et al. 2010). However, the resistance conferred by $P h-3$ is also race-specific, and the isolates virulent on L3708 have already been identified (Chunwongse et al. 2002). Another reported late blight resistant accession is $S$. habrochaites LA1033, which was designated as the source of $P h-4$ (AVRDC 1998). LA1033 was used as one of the differential hosts to classify tomato P. infestans isolates (Kim and Mutschler 2000; Chunwongse et al. 2002). Characterization of $P h-4$ has been hampered because follow-up investigations revealed that the resistance in LA1033 was actually controlled by multiple quantitative trait loci (QTLs) (Lough 2003; Kim and Mutschler 2000). Recently, a new resistant line, S. pimpinellifolium PSLP153, has been discovered which showed resistance against seven different $P$. infestans isolates (Foolad et al. 2006, 2008). Two genomic regions on chromosome 1 (tentatively named $P h-5-1$ ) and chromosome 10 (tentatively named $P h-5-2)$ were identified through a selective genotyping approach (Merk et al. 2012; Merk and Foolad 2012; Nowicki et al. 2012). Efforts are underway to develop commercial breeding lines and hybrid cultivars containing these resistance genes in combination with $P h-2$ and $P h$-3 (Foolad et al. 2008; Nowicki et al. 2012).

Other QTLs conferring race-non-specific resistance have been identified from $S$. pennellii and $S$. habrochaites (Smart et al. 2007; Brouwer et al. 2004; Brouwer and St. Clair 2004; Li et al. 2011a). However, the effects of these QTLs are relatively small and prone to environmental influences. Moreover, linkage drag might complicate the use 
Table 1 Markers used for recombinant screening

\begin{tabular}{llll}
\hline Marker names & Forward primer $\left(5^{\prime}-3^{\prime}\right)$ & Reverse primer $\left(5^{\prime}-3^{\prime}\right)$ & Type of marker \\
\hline G2-4 & ATGCCACGACCATAAATC & GACTGGGCTAATCACGAA & CAPS with DraI \\
R1-3U & AAAAGTATTCAGAGGGGTAA & ATTGCAGATCCATTTCAGT & Co-dominant SCAR \\
R2-3U & TAGTGACACGCTGATAAC & CAATTCTTTGTTGGAGAC & dominant \\
R2M1S & GGAAATCCTCCGCCTTACTT & CGAGTTGCAACCTCTAGACTCA & Co-dominant SCAR \\
TG591S & GCGAGACATAGACCAATC & AACTGGCAGGTGATGTGG & SNP \\
M67-3 & TGCGAATCCTTGTGGTAT & CTTACTGTGGACTGTGGG & CAPS with SspI \\
G7-5 & TGCCTCTGTGAAGATGGT & AAACTGTCGCAGGGTATT & SNP \\
G8-1 & CGCCGTTTCGTGGCATTT & AGCGTGGTGATGGTGTTT & SNP \\
M8-2 & AGGTGTCTCATTCCCATCA & ATAGGGACCAATAGAGGG & InDel \\
\hline
\end{tabular}

(Co-)dominant indicates that it is a (Co-)dominant marker. InDel indicates that this marker is derived from a short Insert/Deletion variation CAPS cleaved amplified polymorphic sequence, SCAR sequence-characterized amplified region, SNP single-nucleotide polymorphism

of these QTLs in breeding programmes (Brouwer and St. Clair 2004).

Currently, introgression or pyramiding of $R$ genes via traditional breeding may not always be possible or too time-consuming. An alternative approach to introduce single or multiple $R$ genes is genetic transformation (Halpin 2005). To achieve durable resistance, three potato Rpi genes were introduced into one genotype through a one-step transformation strategy, and the resulting plants showed an expected broadened resistance spectrum (Zhu et al. 2012, 2013). This approach, however, requires prior knowledge of the gene(s), including mapping, cloning, and functional characterization.

In this study, we performed map-based cloning to isolate $P h$-3, a gene encoding a coiled-coil nucleotide-binding leucine-rich repeat (CC-NBS-LRR) protein. Further, we analysed the $\mathrm{Ph}-3$ protein structure and compared it with other Rpi proteins characterized so far from potato.

\section{Materials and methods}

Plant materials

The S. lycopersicum accessions CLN2037B and CLN2037E, containing the Rpi gene $P h-3$, were kindly provided by the Asian Vegetable Research and Development Center (AVRDC). These two cultivars were crossed with the susceptible tomato breeding line 02393, respectively. Recombinant screening was conducted using the $\mathrm{F}_{2}$ seeds with $P h-3$ flanking markers G2-4 and M8-2 (Table 1). In addition, eight $\mathrm{F}_{3}$ families (B212, B481, N299, N337, N1036, N1097, N1200, N1384), which were derived from the cross between CLN2037B and LA4084 (susceptible) and identified in our previous study (Zhang et al. 2013), were also used for screening recombinants (about 150 plants per $\mathrm{F}_{3}$ family) with the same markers.
Marker development

According to our previous work (Zhang et al. 2013), the target region of $P h-3$ on the Heinz1706 reference genome (http://solgenomics.net) was selected to design PCR primers. Amplified PCR products from the parental lines were sequenced and analysed for polymorphisms in order to produce cleaved amplified polymorphic sequences (CAPS) or insert/deletion (InDel) markers.

\section{Construction and screening of BAC library}

The bacterial artificial chromosome (BAC) library was generated using the $P h-3$ donor species $S$. pimpinellifolium L3708 with restriction enzymes HindIII according to the previously described protocol (van der Voort et al. 1999). The BAC library was stored in 252 384-well microtiter plates, and all 384 clones in one plate were mixed to form a BAC pool. The BAC pool DNA was isolated by alkaline lysis method and screened with two markers TG591S and R2M1S that are closely linked to $P h-3$. Afterwards, the single colony from the 384-well plates corresponding to the positive pool was identified using the same markers. DNA from the single positive colony was isolated and then tested with additional markers covering the $P h-3$ region (Table 1 ).

DNA sequencing and analysis

Sequence of the selected BAC clone harbouring the $P h-3$ region was obtained by constructing a library of subclones (1-3 kb). Both ends of the subclones were sequenced using the ABI 3730xl platform and then assembled (BGI, Beijing, China). Putative genes in the BAC sequence were predicted with the online program FGENESH (http://linux1.softberry.com/) and protein functions were predicted with the InterProScan program (http://ebi.ac. uk/Tools/InterProScan/). Results were compared with 
the Heinz1706 genome annotations derived from the International Tomato Annotation Group (ITAG2.3 version). ClustalW2 was used to align multiple sequences with default settings (http://www.ebi.ac.uk/Tools/msa/ clustalw2/).

Transformation of the $P h-3$ gene into the susceptible $S$. lycopersicum cv. Moneymaker

A 8-kb fragment carrying the $P h-3$ promoter, open reading frame (ORF) and terminator was amplified from the BAC plasmid B25E21 by PCR using the Phusion highfidelity DNA polymerase (Thermo Fisher, Waltham, MA, USA) with primers Ph3EF3 (5'-taacctgcaggTTCAAACCATCTTCATAGAGGC-3') and Ph3ER3 (5'-attggcgcgc$c$ TGGGGCTTAGAAAAAGGTTG-3'). Two enzyme sites $S b f \mathrm{I}$ and $A s c \mathrm{I}$ were added to the $5^{\prime}$ ends of forward and reverse primers, respectively. The PCR product was cloned into pCR-Blunt II-TOPO (Invitrogen, Carlsbad, CA, USA) and sequenced for confirmation. The resulting plasmid was digested with $S b f \mathrm{I}$ and $A s c \mathrm{I}$. The fragment containing the $P h-3$ gene was then ligated into the binary vector pBINPLUS having a modified multiple cloning site. The positive plasmid, named Ph13-2, was introduced into Agrobacterium tumefaciens strain AGL1 by electroporation.

Transformation of S. lycopersicum cv. Moneymaker was carried out as described by Huibers et al. (2013). Twentyfour regenerants that were capable of growing on kanamycin medium were transferred to the greenhouse. All kanamycin resistant regenerants were screened with the primer pair M67-3F (5'-TGCGAATCCTTGTGGTAT-3', located in the $P h-3$ fragment) and pBP-R2 (5'-AGGGAAGAAAGCGAAAGGAG- $3^{\prime}$, located in the vector but within the T-DNA region).

\section{Disease assay}

Both whole-plant assay (WPA) and detached-leaf assay (DLA) were used for disease tests with $P$. infestans. The progenies of two recombinants (1-356 and 8-25) were tested by WPA as described by Zhang et al. (2013). The recombinants and $P h-3$ transgenic plants were tested for $P$. infestans resistance through DLA as described by Vleeshouwers (1999). Three leaves of each plant were used and inoculated with $P$. infestans isolate $\mathrm{T}_{1,2,4}$ (Zhang et al. 2013). Two independent disease tests were performed for DLA.

RNA isolation and quantitative real-time PCR

Total RNA was extracted using RNeasy plant mini kit (Qiagen, Hilden, Germany). First-strand cDNA was synthesized with the iScript cDNA synthesis kit (Bio-Rad,
Hercules, CA, USA). cDNA was diluted tenfold and used for real-time PCR (RT-PCR) with the Bio-Rad CFX96 ${ }^{\mathrm{TM}}$ thermal cycler according to the protocol provided by the manufacturer. To detect the expression of $R$ gene analogues (RGAs) in CLN2037B, samples were taken from three plants, and for each plant three leaves were pooled for RT-PCR. The primers R1eF1 (5'-GAAAGGGATGCAAGAACCAA- $3^{\prime}$ ) and R1eR1 (5'-CGACAAACTTGTTGGCAGAA-3') located in ORF2, which produced a 181-bp fragment, were used to test the expression of ORF2. The primers used to check the expression of ORF3 were R2 $\mathrm{eF} 1$ (5'-TTCTTCTTACTGCAGTCGTCAA- $\left.{ }^{\prime}\right)$ and R2eR1 ( $5^{\prime}$-TCCAACTTCCTTTGCCTTTG- $\left.3^{\prime}\right)$, which produced a 164-bp fragment. For analysis of the $P h-3$ expression level in the primary transgenic plants, the primers R2eF1 and $\mathrm{R} 2 \mathrm{eR} 1$ were used. The tomato elongation factor $1 \alpha$ $(E F 1 \alpha)$ gene (Gene ID: 544055) was used as the internal reference in all analyses which was amplified with forward (5'-ATTGGAAACGGATATGCTCCA-3') and reverse primers (5'-TCCTTACCTGAACGCCTGTCA-3'). Gene expression level was calculated on the basis of the $2^{-\Delta \Delta \mathrm{Ct}}$ method (Livak and Schmittgen 2001).

\section{Results}

Fine mapping of the $P h-3$ gene

Previously, $P h-3$ was mapped into a 74-kb interval on the long arm of chromosome 9 (Zhang et al. 2013). In this region, eight genes were identified in the Heinz1706 reference genome (The Tomato Genome Consortium 2012). To further narrow down the $P h-3$ interval, approximately 1,900 plants from two $\mathrm{F}_{2}$ populations $(\mathrm{CLN} 2037 \mathrm{~B} \times 02393$ and CLN2037E $\times$ 02393) and eight $\mathrm{F}_{3}$ populations (derived from CLN2037B $\times$ LA4084) were screened with two markers G2-4 and M8-2 flanking the $P h-3$ gene (Table 1). Seven recombinants were identified and genotyped with additional markers located in between G2-4 and M8-2. Three leaves of each recombinant were inoculated with $P$. infestans isolate $\mathrm{T}_{1,2,4}$ through DLA. In two independent experiments, five recombinants (1-104, 4-35, 1-356, 7-111, 4-54) containing the $S$. pimpinellifolium L3708 introgression between markers G2-4 and M67-3 were resistant, while two recombinants (8-25 and 2-125) lacking this introgression were susceptible (Table 2). This result indicated that $P h-3$ was located in between markers G2-4 and M67-3, a region of $41 \mathrm{~kb}$ in the Heinz1706 genome. The progenies of two important recombinants (1-356 and 8-25) were tested with $P$. infestans using the whole-plant assay. In the progeny of 1-356, two out of the 10 tested plants were susceptible, suggesting that the $P h-3$ gene was located in the heterozygous region, upstream of the marker M67-3. All 27 progeny plants from 8-25 were 
Table 2 Phenotype and genotype of the identified recombinants

\begin{tabular}{|c|c|c|c|c|c|c|c|c|c|c|c|}
\hline \multirow[t]{2}{*}{ Recombinants } & \multirow[t]{2}{*}{ Populations } & \multicolumn{9}{|c|}{ Marker name and genotype } & \multirow[t]{2}{*}{ Phenotype } \\
\hline & & G2-4 & $\mathrm{R} 1-3 \mathrm{U}$ & $\mathrm{R} 2-3 \mathrm{U}$ & R2M1S & TG591S & M67-3 & G7-5 & G8-1 & M8-2 & \\
\hline $1-104$ & $\mathrm{~F}_{2}$ of CLN2037B $\times 02393$ & $\mathrm{~b}$ & $\mathrm{~h}$ & $\mathrm{~h}$ & $\mathrm{~h}$ & $\mathrm{~h}$ & $\mathrm{~h}$ & $\mathrm{~h}$ & $\mathrm{~h}$ & $\mathrm{~h}$ & $\mathrm{R}$ \\
\hline $4-35$ & $\mathrm{~F}_{3}$ of B481 from CLN2037B $\times$ LA4084 & $\mathrm{b}$ & $\mathrm{h}$ & $\mathrm{h}$ & $\mathrm{h}$ & $\mathrm{h}$ & $\mathrm{h}$ & $\mathrm{h}$ & $\mathrm{h}$ & $\mathrm{h}$ & $\mathrm{R}$ \\
\hline $8-25$ & $\mathrm{~F}_{3}$ of $\mathrm{N} 337$ from CLN2037B $\times$ LA4084 & $\mathrm{h}$ & $\mathrm{h}$ & $\mathrm{h}$ & $\mathrm{h}$ & $\mathrm{a}$ & a & a & a & a & $\mathrm{S}$ \\
\hline $1-356$ & $\mathrm{~F}_{2}$ of CLN2037B $\times 02393$ & $\mathrm{~h}$ & $\mathrm{~h}$ & $\mathrm{~h}$ & $\mathrm{~h}$ & $\mathrm{~h}$ & $\mathrm{~b}$ & $\mathrm{~b}$ & $\mathrm{~b}$ & $\mathrm{~b}$ & $\mathrm{R}$ \\
\hline $7-111$ & $\mathrm{~F}_{3}$ of B212 from CLN2037B $\times$ LA4084 & $\mathrm{h}$ & $\mathrm{h}$ & $\mathrm{h}$ & $\mathrm{h}$ & $\mathrm{h}$ & $\mathrm{h}$ & a & a & a & $\mathrm{R}$ \\
\hline $2-125$ & $\mathrm{~F}_{2}$ of CLN2037E $\times 02393$ & a & a & a & a & $\mathrm{a}$ & a & a & l & $\mathrm{h}$ & $\mathrm{S}$ \\
\hline $4-54$ & $\mathrm{~F}_{3}$ of B481 from CLN2037B $\times$ LA4084 & $\mathrm{b}$ & $\mathrm{b}$ & $\mathrm{b}$ & $\mathrm{b}$ & $\mathrm{b}$ & $\mathrm{b}$ & $\mathrm{b}$ & $\mathrm{b}$ & $\mathrm{h}$ & $\mathrm{R}$ \\
\hline
\end{tabular}

$a$, homozygous like the susceptible parent; $b$, homozygous like the resistant parent; $h$, heterozygous; /, not determined

Fig. 1 Physical map of the $P h-3$ genomic region from $S$. pimpinellifolium L3708. a Positions of markers in BAC clone B25E21. Indel-3 and P-55 were previously identified $P h$-3 flanking markers (Zhang et al. 2013). b The predicted ORFs between markers G2-4 and M8-2

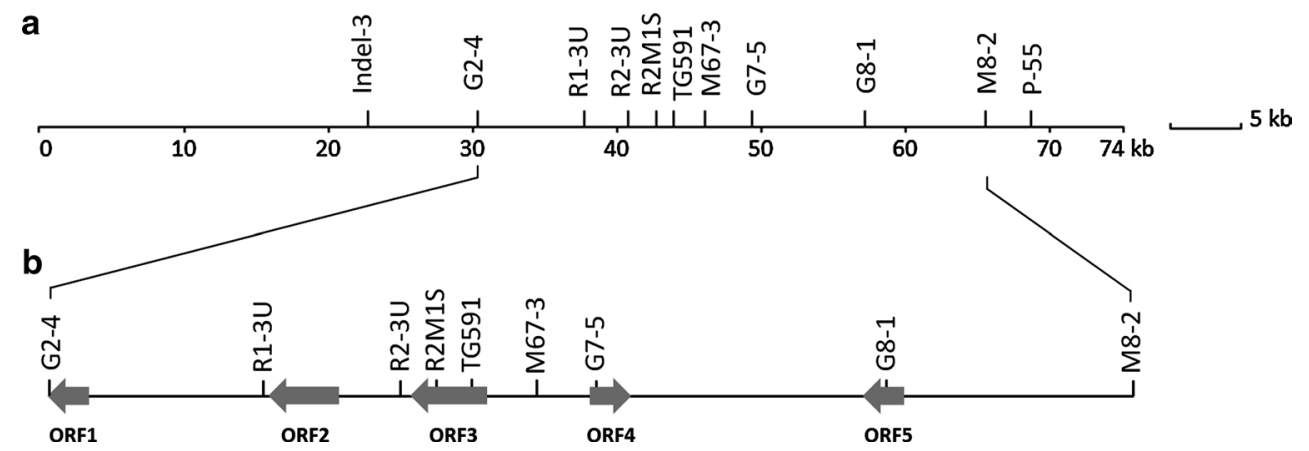

susceptible confirming that the introgression between markers G2-4 and R2M1S did not carry the late blight resistance. Therefore, the $P h-3$ gene was delimited to a $26 \mathrm{~kb}$ region between markers R2M1S and M67-3 based on the Heinz1706 reference genome.

\section{BAC library screening}

In the previous study, we have demonstrated that the $P h-3$ gene belongs to a CC-NBS-LRR gene family at the end of the long arm of chromosome 9. In the Heinz1706 genome, there are four members of this gene family present in the 74-kb interval where $P h-3$ is located (Zhang et al. 2013). We thus tried to amplify the full length of the homologous alleles in S. pimpinellifolium L3708 (the donor of the $P h-3$ gene). Unfortunately, primers designed according to the Heinz1706 reference genome failed to amplify the full length of candidate homologs from the $P h$-3-carrying tomato lines. In order to obtain the sequence covering the Ph-3 locus, the Ph-3 donor S. pimpinellifolium L3708 was used to construct a BAC library. The library consisted of 96,768 clones with an average insert size of $100 \mathrm{~kb}$ based on pulsed-field gel analysis of randomly selected clones. The library was thus estimated to represent approximately tenfold coverage of the L3708 genome.

Two PCR markers R2M1S and TG591S (Fig. 1), which were closely linked to $P h-3$, were used to screen the BAC library. A positive BAC pool B25 was identified from which a positive clone B25E21 was picked up. Subsequently, the full length of B25E21 was sequenced. The whole BAC sequence of B25E21 carries an insert of 73,671 bp from $S$. pimpinellifolium L3708, corresponding to an interval of $101,456 \mathrm{bp}$ in the Heinz1706 reference genome starting from SL2.40ch09:66725592 and ending at SL2.40ch09:66827013. The sequence alignment showed that the first $29 \mathrm{~kb}$ and the last $37 \mathrm{~kb}$ of BAC clone B25E21 were collinear with the reference sequence except two short deletions in the first $10 \mathrm{~kb}$ (Fig. 2). The major difference was the high variable region in the middle, starting at about $66,762 \mathrm{~kb}-66,795 \mathrm{bp}$ based on the Heinz1706 genome.

All markers used for screening recombinants (Table 1) were found in the BAC sequence (Fig. 1a). In total, five ORFs between the $P h-3$ flanking markers G2-4 and M8-2 were predicted. Among them, ORF1 encodes a transferase, ORF2 and ORF3 are RGAs encoding CC-NBS-LRR type of $\mathrm{R}$ proteins, ORF4 encodes an RNA binding protein-like protein and ORF5 encodes an NAD-dependent epimerase (Fig. 1b).

\section{Candidate of $P h-3$}

In the previous study, we have demonstrated that $P h-3$ is an RGA of an NBS-type family (Zhang et al. 2013). In the Heinz1706 genome, the $P h-3$ interval carries four RGA 
Fig. 2 Comparison of the $\mathrm{Ph}$-3-containing BAC sequence with the Heinz1706 reference sequence. The $X$-axis shows the sequence of BAC B25E21, and the $Y$-axis shows the corresponding Heinz1706 reference sequence. The sequences were analysed using dottup (v6.0.1) with a window size 10. Arrow points to the large picture of the variable region carrying RGAs

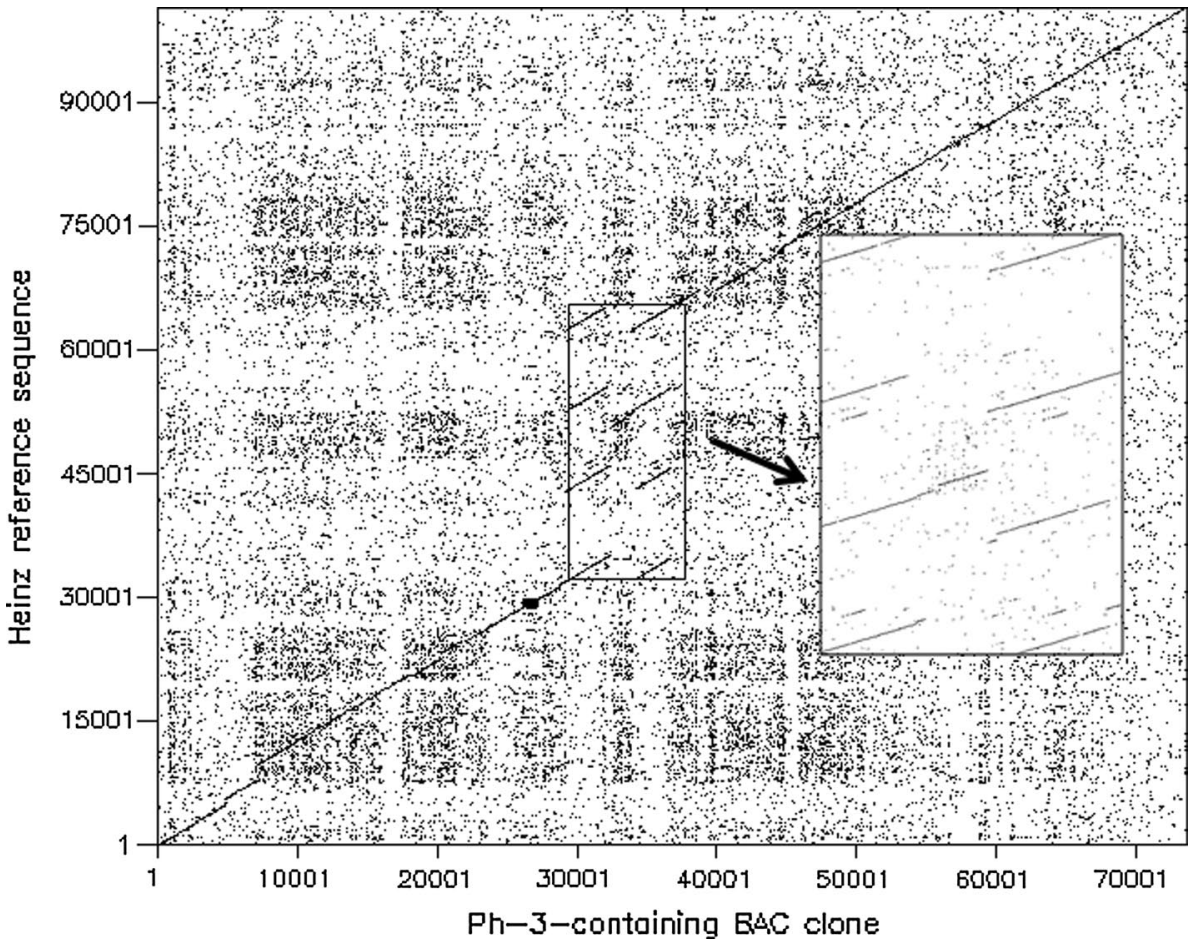

Ph-3-contoining BAC clone

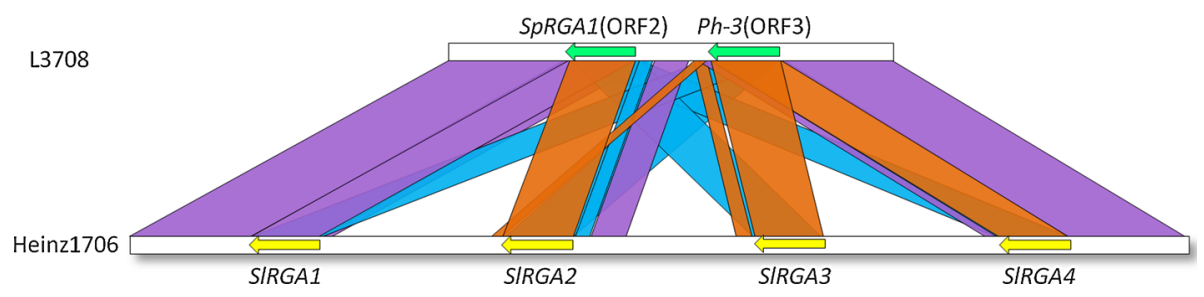

Fig. 3 Schematic of the microsynteny between the $R$ gene clusters at the $P h-3$ locus in S. pimpinellifolium L3708 and S. lycopersicum Heinz1706. The green arrows at the top show the $R$ gene homologs in the L3708 BAC sequence, and the yellow arrows at the bottom indicate RGAs at the corresponding locus of Heinz1706. The

members (SIRGA1-SIRGA4). However, in S. pimpinellifolium L3708 genome, it contains only two RGAs (ORF2 and ORF3) (Fig. 3), which show different nucleotide identity to the four RGAs in the Heinz1706 genome (Fig. 3; Table S1). In the tomato line CLN2037B carrying the $P h-3$ gene, the expression of ORF3 but not ORF2 was detected (Fig. S1). Since $P h-3$ was mapped to a $26 \mathrm{~kb}$ interval between markers R2M1S and M67-3 (Table 2), a region harbouring only ORF3, the ORF2 was thus excluded to be the $P h-3$ candidate.

The key recombinant 8-25 which resulted from recombination events in the RGAs region was analysed. This susceptible recombinant is heterozygous at the R2M1S locus while it is homozygous for the LA4084 allele at the TG591S locus. Both R2M1S and TG591S are located within ORF3. The progeny plants of the recombinant 8-25, which was homozygous for the CLN2037B allele at transcriptional orientations are indicated by the direction of arrows. The orange, purple and blue lines linking the L3708 and Heinz1706 sequences indicate an identity above $95,90-95$, and $85-90 \%$, respectively

R2M1S locus and homozygous for the LA4084 allele at TG591S locus were selected and used to amplify the DNA fragment with the R2M1S forward primer and the TG591S reverse primer. Subsequently, this sequence was aligned with the alleles from S. pimpinellifolium L3708 and the susceptible parent LA4084. In this way, the crossing-over event of 8-25 was pinpointed between two SNPs (Fig. 4) which are 465 bp apart. Since all progeny plants of 8-25 were susceptible, it is very likely that the recombination event in 8-25 led to a non-functional chimeric ORF3, suggesting that ORF3 was the most likely candidate of $P h-3$.

Complementation analysis

To analyse the function of the $P h-3$ candidate gene, a fragment encompassing 3,565 bp upstream and 1,866 bp 


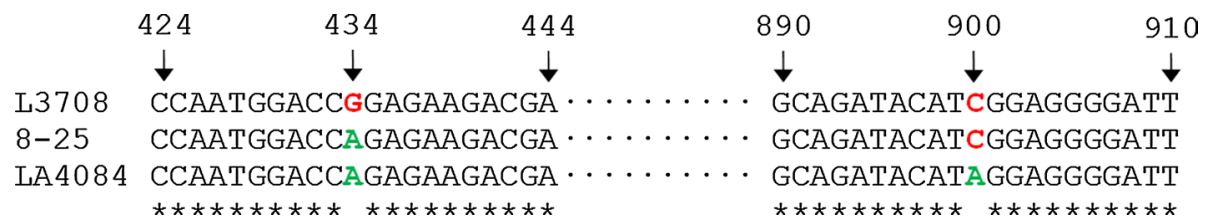

Fig. 4 The recombination point in the key recombinant 8-25. The ORF3 fragments from the $P h-3$ donor plant L3708, the susceptible parent LA4084 and the susceptible recombinant 8-25 were aligned.
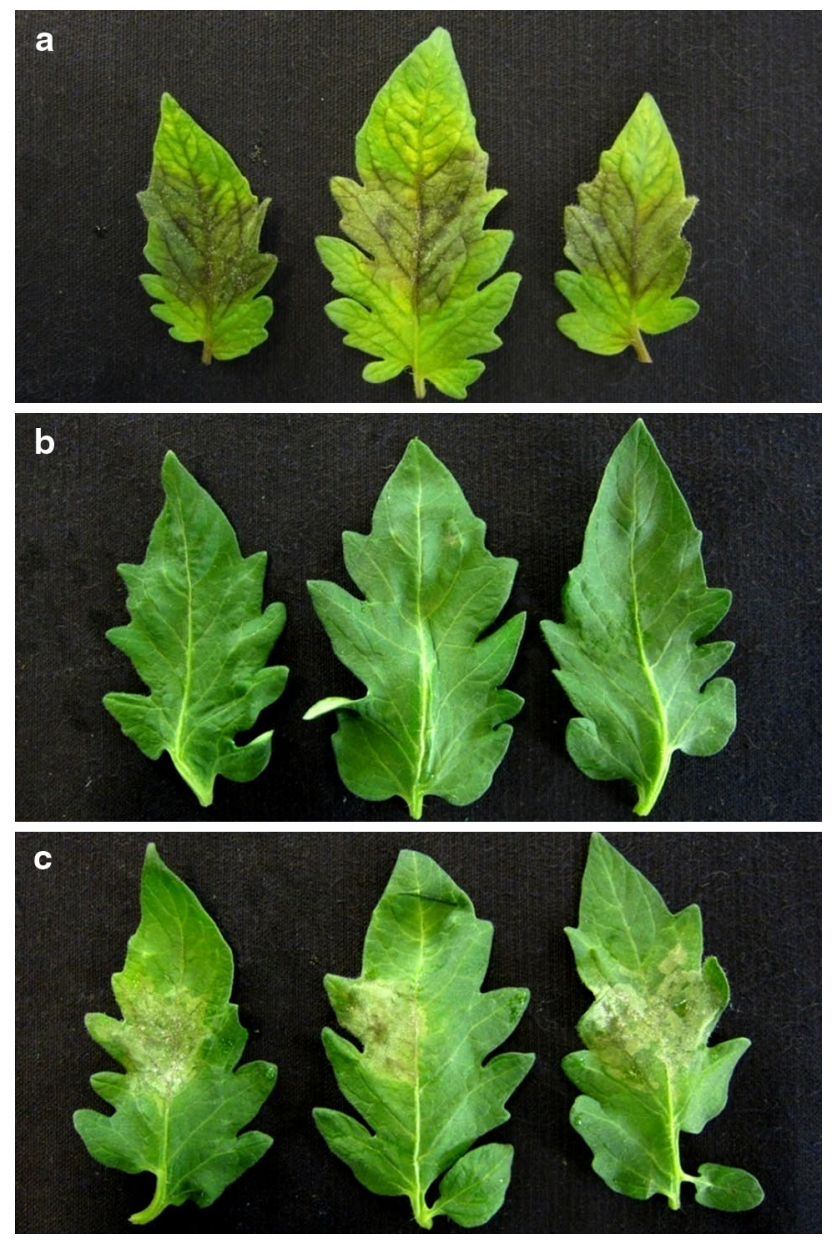

Fig. 5 Expression of the resistant allele of $P h-3$ in susceptible Moneymaker resulted in resistance to $P$. infestans. Transgenic lines were tested in two independent experiments. a Non-transformed Moneymaker showed mycelium growing on the infected leaf areas; b transformed Moneymaker expressing $P h-3$ showed no symptom and c transformed Moneymaker not expressing $P h-3$ showed mycelium growing on the infected leaf areas. It is worthwhile to note that nontransformed Moneymaker plants were grown from seeds and that transformed Moneymaker were from cuttings. Three leaflets in $\mathbf{a}, \mathbf{b}$ or c were taken from one inoculated leaf and three leaves per plant were tested. Photographs were taken 7 days post-inoculation

downstream of ORF3 was amplified from BAC clone B25E21 and cloned into the binary vector pBINPLUS. The resulting plasmid was used for Agrobacterium-mediated
Based on two SNPs (residues 434 and 900) in this region, the recombination site of 8-25 was located within the ORF3. The numbers above the arrows indicate the positions of nucleotides in the ORF3

transformation of the susceptible tomato cv. Moneymaker. In total, 14 independent transformants containing the $P h-3$ gene were obtained and tested for resistance to $P$. infestans isolate $\mathrm{T}_{1,2,4}$. Among them, nine transgenic plants were resistant to $P$. infestans, while the remaining five plants were susceptible (Fig. 5; Fig. S2). Compared with CLN2037B, all resistant transgenic plants except CZ-T04 showed comparable or higher expression levels of the $P h-3$ gene (Fig. S2). Therefore, the ORF3 under the control of its native promoter and terminator was sufficient to provide resistance to $P$. infestans in the susceptible Moneymaker plants, showing that ORF3 is the $P h-3$ gene.

\section{Structure of $P h-3$}

The $P h-3$ gene (GenBank accession number: KJ563933) consists of one exon of 2,556 nucleotides, encoding a predicted polypeptide of 851 amino acids (Fig. 6). The deduced $\mathrm{Ph}-3$ protein belongs to the CC-NBS-LRR class of plant $\mathrm{R}$ proteins. A predicted coiled-coil (CC) structure is located in the $\mathrm{N}$-terminus between amino acids 63 and 84. Therefore, the entire $\mathrm{N}$-terminus, from amino acid 1 till 150, is referred to as the CC domain. The NBS domain resides between residues 151 and 449, where the conserved NB-ARC motifs are present (van der Biezen and Jones 1998; Meyers et al. 2003). It is remarkable that the $\mathrm{HD}$ ( $\mathrm{H}$ means histidine and $\mathrm{D}$ means aspartic acid) domain is located within the predicted LRR region, like the proteins encoded by $R 9 a$ and $T m-2^{2}$ (Jo 2013; Lanfermeijier et al. 2003). The $C$ terminal sequence only loosely fits the consensus for intracellular leucine-rich repeats (LRR), LxxLxxLxLxxC/Nxx (where L represents Leu, Ile, Val or Phe, $\mathrm{N}$ stands for Asp, Thr, Ser or Cys, and $\mathrm{x}$ is any amino acid) (van Ooijen et al. 2007). However, the consensus sequence for the $\beta$-sheet core (xxLxLxx) could be distinguished and totally 16 irregular LRR were found.

Among the cloned potato Rpi genes, $P h-3$ shares high identity ranging 74.7-78.7 \% to three chromosome-9-derived potato Rpi genes, Rpi-vnt1.1 from S. venturii, Rpimcql from $S$. mochiquense and $R 9 a$ from $S$. demissum (Foster et al. 2009; Pel et al. 2009; Jones et al. 2009; Jo 2013) (Table S2). As shown by other studies (e.g. Jupe et al. 2013; Parniske et al. 1997), the lowest identity among 
Fig. 6 The domain structure of the predicted $\mathrm{Ph}-3$ protein. The predicted coiled coil in the $\mathrm{CC}$ domain was underlined. Boxes indicate positions of conserved NB-ARC motifs. The 16 imperfect LRRs were aligned according to the consensus sequence xxLxLxx (where L represents leucine or other aliphatic amino acid, and $\mathrm{x}$ is any residue)
CC

MADILLTAVVNKSVEIAANLLVQEGTRLHWLREDI DWLQREMRHIRSYVDDAKAKEVGGDSRVKNLLEDIQQLAGD VEDLLDEFLPKIQQSNKFICCLKTVSFADKFAMEIEKI KRRVADI DRVRTTYNITDT SNNNDDCI PMDRRRRFL

NBS

Kinase-1a

HANDETEVIGLDHDFNKLQHKLLLQDL PYGVVS IVGMPGLGKTTLAKKLY RHVRHQFECSGLVYVSQQPRAGE ILL Kinase-2 Kinase $3 a$

NIAKQVGLTEEERKENLEHNLRSL IKIKRYVILIDDIWDVE IWDDLKLVL PESDSKI GSRIIITSRNSNVGRYIGG RNBS -C GLPL

DFS IHELQP IDSENSFEIFTKKICNFVDDNWANTS PDLVNIGRC IVERCGGIPLAIVVTAGMLRARGRTEHAWNRV RNBS-D

LDSMTHKIQEGCAKVLALSYNDIPIALRPCFLYFGLFPEDHEIRAFDLINMW IAEKLIVVNSGNTREAE

\section{LRR}

01 SKAEDFI NDIVSRN LIQVAKRRYDGRIST

HD

02 CRIHDLI HSLCVEL GKESNFFHTEHNAFGD

03 PGNVSRV RRITFYS DINAMNEFLRS

04 NPNPKKI RALFCFI GDSCLFSQLA

05 RHDFKLI QVLVVVI AYDYFLSYMGIPNT

06 FGKTSCI RYLQLEG NMRGKLP

07 NSMVKHM QTLNIEN SCTELPTV

08 VWESKQI RHVRYRV GFEASNCCFSI

09 SRKIYSL PPNNIQT LMCVYDKFVEQIL

10 FHRLINI RKLGLWI VSDFTVQIL

11 STLPKEL EDLKLIF SCQPSEQMN

12 LSSYPYI VKLHLSG NVHLNS

13 VTFPPNL VKLTLRL IMVEGYV

14 VALLKKL SKLRILK MIWCKHKEEKMDLSGD

15 GDSFLQI EVLYIQE PSGLSEVECTD

16 DVSMPKL KKLLLKE IPNSNLRLSKRLAKLRV

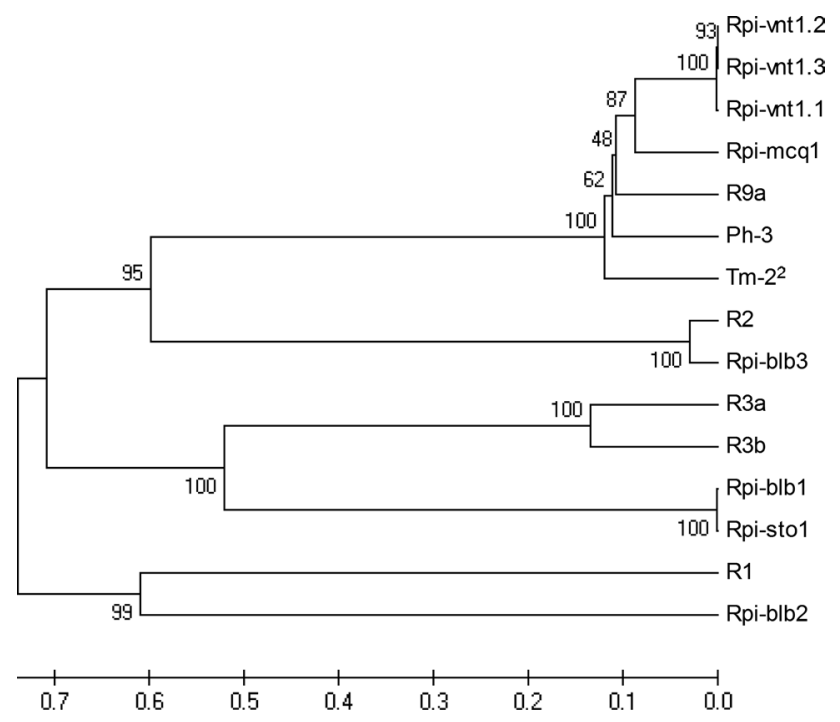

Fig. 7 Phylogenetic analysis of $T m-2^{2}$-like resistance proteins and all cloned potato Rpi proteins. The resistance protein sequences were downloaded from GenBank (http://www.ncbi.nlm.nih.gov/genbank/). The phylogenetic tree was performed using MEGA4 with Bootstrap test. Numbers at the branches are confidence values

these Rpi proteins was found in the LRR domain. Taking $P h-3$ and Rpi-vnt1.1 as an example, the identity in LRR domain is $63.3 \%$ while the CC and NBS domains show an identity of 90.7 and $91.4 \%$, respectively. In addition, $P h-3$ also shares high amino acid identity to the tomato mosaic virus resistance gene $T m-2^{2}$ from $S$. peruvianum, which is located near the centromere of chromosome 9 (Table S2) (Lanfermeijier et al. 2003). All chromosome-9-derived proteins (Ph-3, Rpi-vnt1.1, Rpi-vnt1.2, Rpi-vnt1.3, Rpi-mcq1, R9a and Tm- $2^{2}$ ) belong to one clade (Fig. 7), which is distinct from other identified potato Rpi proteins.

\section{Discussion}

In a previous study, we have demonstrated that $P h-3$ belongs to the NBS-LRR $R$ gene cluster on chromosome 9 (Zhang et al. 2013). Unfortunately, the full length of candidate $R$ gene homologs could not be amplified from the $P h$-3-containing tomato lines with the primers designed according to the Heinz1706 reference genome. The failure in such a homology-based cloning was likely due to SNPs present in sequence of $S$. pimpinellifolium L3708 compared to the Heinz1706 reference genome (Fig. 2). We have therefore taken a map-based cloning approach for cloning of the $P h-3$ gene, which is the first cloned tomato late blight $R$ gene. Like the most cloned $R$ genes, the $P h-3$ gene also belongs to the NBS-LRR complex. Compared with the tomato Heinz1706 genome sequence, there is a deletion in 
the $P h-3$ region of $S$. pimpinellifolium L3708 where RGAs are clustered. In Heinz1706, there are four RGAs while in L3708 there are only two RGAs. One of the two RGAs, ORF3, is confirmed to be the $P h-3$ gene.

\section{A hotspot carrying Rpi genes on chromosome 9 of Solanum species}

It is well known that the NBS-LRR class of $R$ genes is often clustered in the genome as a result of tandem and segmental duplications (Hulbert et al. 2001; Leister 2004; McDowell and Simon 2006). Occasionally, all $R$ genes in one cluster are functional, as is the case for $R 3$ locus for late blight resistance in potato (Huang et al. 2005; Li et al. 2011b). In this study, however, only one RGA in the $P h$ 3 cluster contributes to the resistance for late blight. The $P h-3$ gene is located at the end of the long arm of chromosome 9, a region carrying many Rpi genes in Solanaceae. In Solanum species, Rpi genes including Rpi-vnt1.1, Rpimcql, R8, R9a, Rpi-edn2 and Rpi-dlc1, are located in this region (Pel et al. 2009; Smilde et al. 2005; Jo et al. 2011; Jo 2013; Verzaux 2010; Golas et al. 2010). Due to high variability of $R$ gene clusters across species and lack of flanking sequences of these Rpi genes, it is hard to determine if all or any of these genes are orthologs of $P h-3$. Nevertheless, $P h-3$ exhibits highest identity to Rpi-vnt1.1, Rpi-mcql and $R 9 a$. These Rpi proteins are quite conserved in the $\mathrm{CC}$ and NBS domain (Jupe et al. 2013), while there is a high degree of amino acid variability in predicted solvent exposed residues of the LRR parallel $\beta$-sheet structure, a determinant of recognition specificity (Parniske et al. 1997).

The changes of generating a gain of function allele by random mutation alone are extremely low (Parniske and Jones 1999). Evolution of $R$ genes is driven by gene duplication and unequal crossing-over followed by diversifying selection (Michelmore and Meyers 1998; Hulbert et al. 2001). For example, the presence of tandemly duplicated homologous sequences at the $C f-4 / C f-9$ locus promote chromosome mispairing followed by unequal crossing-over or gene conversion events (Thomas et al. 1997). In the $P h$ 3 cluster, there are two and four RGAs in S. pimpinellifolium L3708 and S. lycopersicum Heinz1706, respectively. All RGAs in these two genomes share high identity with each other ranging from $87.8 \%$ (SIRGAl and SlRGA3) to $97.5 \%$ (SlRGA3 and SlRGA4) (Table S1), which possibly promotes the unequal homologous recombination. Furthermore, we indeed showed that the $P h-3$ allele in the recombinant 8-25 resulted from an unequal crossover between the $P h-3$ gene and the susceptible allele, which led to a chimeric and non-functional RGA. It suggests that chromosomal rearrangements within $R$ gene clusters do occur, resulting in the formation of a novel allele.

\section{A combined use of tomato and potato Rpi gene to achieve durable resistance}

Both tomato and potato are hosts of $P$. infestans. The resources of late blight resistance in tomato germplasm are less abundant than in the potato. So far, all tomato Rpi genes, which are useful for resistance breeding, are identified in the wild species $S$. pimpinellifolium (Bonde and Murphy 1952; Gallegly and Marvel 1955; Peirce 1971; Moreau et al. 1998; Black et al. 1996a, b; Chunwongse et al. 2002; Foolad et al. 2006, 2008; Merk et al. 2012; Merk and Foolad 2012). Although $P h-3$ is widely used in tomato breeding, the resistance of $P h-3$ has been overcome. Chunwongse et al. (2002) reported that four isolates were virulent on the $P h-3$ donor L3708. Therefore, it is necessary to investigate if other wild relatives of tomato can provide novel monogenic Rpi genes conferring race-nonspecific resistance.

Durable disease resistance is the ultimate goal of many breeding programmes. Durable resistance has no particular genetic basis. It is a consequence of both the nature of resistance in the plant and the evolutionary potential of the pathogen (Michelmore et al. 2013). Some monogenic $R$ genes, such as $L r 34$ in wheat, mlo in barley and other species, have proved durable over many years of agricultural use (Krattinger et al. 2013; Jørgensen 1992; Bai et al. 2008). For late blight, however, single $R$ genes were quickly overcome in the field. Stacking of two or multiple $R p i$ genes can confer resistance to a broad and complementary set of isolates (Zhu et al. 2012, 2013). For stacking strategy, the knowledge of interaction between $P$. infestans (effectors) and host ( $R$ genes) is essential, which helps to evaluate the durability of $R$ genes (Vleeshouwers et al. 2008). The $P h-3$ gene has high identity with two potato $R p i$ genes (Rpi-vnt1.1 and R9a) of which corresponding effectors are known (Pel 2010; Jo 2013). Whether $P$ h-3 recognizes these effectors is still not clear.

An alternative approach to manage late blight in tomato is to introduce potato Rpi genes into tomato. It has been reported that the potato Rpi genes Rpi-blbl, Rpi-blb2, R1, R3a, Rpi-vntl.l, and Rpi-mcql were functional in tomato (van der Vossen et al. 2003, 2005; Jia et al. 2009; Foster et al. 2009; Jones et al. 2009). The Rpi-blb1 or Rpi-blb2 transgenic tomato plants not only showed resistance to $P$. infestans isolates from potato, but also to the isolates from tomato (van der Vossen et al. 2003, 2005; Jia et al. 2009), which illustrates the potential effectiveness of the employment of potato Rpi genes in tomato. Furthermore, we observed that the tomato line CLN2037B containing $P h-3$ were resistant to multiple potato isolates (data not shown), suggesting that $P h-3$ could protect potato from late blight. However, Oyarzun et al. (1998) observed a greater specificity of isolates for their first host than for their alternative 
host. Also Vega-Sánchez et al. (2000) found that tomato and potato were attacked by two separate, host-adapted populations of $P$. infestans. Therefore, it is still unclear that the resistance to potato isolates is mediated by the $P h$ 3 gene or other host or pathogen factors. In addition, the $P h-3$ gene provides only partial resistance (Zhang et al. 2013). Although complete resistance was achieved when the $P h-3$ gene was highly expressed under its native promoter, an absolute correlation between gene expression level and resistance was not found (Fig. S2). Compared to CLN2037B, the $P h-3$ gene was significantly higher expressed in three transgenic plants (T10, T09, T15) which showed no symptoms on the inoculated leaves. However, not all transgenic plants having a similar level of expression as the one in CLN2037B showed resistance. One possible reason is the difference at insertion locations of the $P h-3$ gene. Alternatively, the expression of $P h-3$ might be influenced by developmental stages and environments because leaves used for inoculation and RNA extraction were different. Thus, the resistance level in these transgenic tomato lines needs to be confirmed by testing their progenies. Further, transformation of $P h-3$ into susceptible potato cultivars and analysis of their resistance level and spectrum will verify the potential effectiveness of the employment of $P h$ 3 in potato breeding programmes.

Acknowledgments This study was funded by the National High Technology Research and Development Program of China (863 Program, No. 2012AA100101 and No. 2012AA100103), the National Natural Science Foundation of China (31171975), China Agriculture Research System (CARS-25), Agricultural Biology Resource Innovation Project, Breeding Program of Shandong Province, China (PTBR2013) and the Key Laboratory of Horticultural Crops Genetic Improvement, Ministry of Agriculture of the People's Republic of China.

Conflict of interest All benefits in any form from a commercial party related directly or indirectly to the subject of this manuscript or any of the authors have been acknowledged. The authors of this manuscript declare that they have no conflict of interest.

Open Access This article is distributed under the terms of the Creative Commons Attribution License which permits any use, distribution, and reproduction in any medium, provided the original author(s) and the source are credited.

\section{References}

AVRDC (1995) 1994 Progress Report. Asian Vegetable Research and Development Center, Taiwan, pp 194-197

AVRDC (1998) AVRDC Report 1997. Asian Vegetable Research and Development Center, Taiwan, pp 83-84

AVRDC (1999) AVRDC Report 1998. Asian Vegetable Research and Development Center, Taiwan, pp 9-13

Bai Y, Pavan S, Zheng Z, Zappel NF, Reinstädler A, Lotti C, De Giovanni $\mathrm{C}$, Ricciardi L, Lindhout $\mathrm{P}$, Visser R, Theres $\mathrm{K}$, Panstruga R (2008) Naturally occurring broad-spectrum powdery mildew resistance in a Central American tomato accession is caused by loss of Mlo function. Mol Plant Microbe Interact 21:30-39

Black LL, Wang TC, Hanson P, Chen JT (1996a) Late blight resistance in four wild tomato accessions: effectiveness in diverse locations and inheritance of resistance. J Phytopathol 86:S24

Black LL, Wang TC, Hanson P, Chen JT (1996b) New sources of late blight resistance identified in wild tomatoes. TVIS Newsl $1: 15-17$

Bonde R, Murphy EF (1952) Resistance of certain tomato varieties and crosses to late blight. Maine Agr Exp Sta Bull 497:5-15

Brouwer DJ, St. Clair DA (2004) Fine mapping of three quantitative trait loci for late blight resistance in tomato using near isogenic lines (NILs) and sub NILs. Theor Appl Genet 108:628-638

Brouwer DJ, Jones ES, St. Clair DA (2004) QTL analysis of quantitative resistance to Phytophthora infestans (late blight) in tomato and comparisons with potato. Genome 47:475-492

Chowdappa P, Kumar NBJ, Madhura S, Kumar MSP, Myers KL, Fry WE, Squires JN, Cooke DEL (2013) Emergence of 13_A2 blue lineage of Phytophthora infestans was responsible for severe ourbreaks of late blight on tomato in South-West India. J Phytopathol 161:49-58

Chunwongse J, Chunwongse C, Black L, Hanson P (2002) Molecular mapping of the $P h-3$ gene for late blight resistance in tomato. J Hort Sci Biotechnol 77:281-286

Cooke DEL, Cano LM, Raffaele S, Bain RA, Cooke LR, Etherington GJ, Deahl KL, Farrer RA, Gilroy EM, Goss EM, Grünwald NJ, Hein I, MacLean D, McNicol JW, Randall E, Oliva RF, Pel MA, Shaw DS, Squires JN, Taylor MC, Vleeshouwers VGAA, Birch PRJ, Lees AK, Kamoun S (2012) Genome analyses of an aggressive and invasive lineage of the Irish potato famine pathogen. PLoS Pathog 8(10):e1002940. doi:10.1371/journal.ppat.1002940

Foolad MR, Merk HL, Ashrafi H, Kinkade MP (2006) Identification of new sources of late blight resistance in tomato and mapping of a new resistance gene. In: 21st Ann. Tomato Disease Workshop 4-7. North Carolina State University, North Carolina State University, Fletcher, NC

Foolad MR, Merk HL, Ashrafi H (2008) Genetics, genomics and breeding of late blight and early blight resistance in tomato. Crit Rev Plant Sci 27:75-107

Foster SJ, Park T, Pel M, Brigneti G, Śliwka J, Jagger L, van der vossen E, Jones JDG (2009) Rpi-vnt1.1, a $T m-2^{2}$ homolog from Solanum venturii confers resistance to potato late blight. Mol Plant Microbe Interact 22:589-600

Fry W (2008) Phytophthora infestans: the plant (and $R$ gene) destroyer. Mol Plant Pathol 9:385-402

Gallegly ME, Marvel ME (1955) Inheritance of resistance to tomato race-0 of Phytophthora infestans. J Phytopathol 45:103-109

Gardner RG, Panthee DR (2010a) NC 1 CELBR and NC 2 CELBR: early blight and late blight-resistant fresh market tomato breeding lines. HortScience 45:975-976

Gardner RG, Panthee DR (2010b) 'Plum Regal' fresh-market plum tomato hybrid and its parents, NC 25P and NC30P. HortScience 45:824-825

Gevens AJ, Seidl AC (2013) First report of late blight caused by Phytophthora infestans clonal lineage US-22 on tomato and potato in Wisconsin. Plant Dis 97:423

Golas TM, Sikkema A, Gros J, Feron RMC, van den Berg RG, van der Weerden GM, Mariani C, Allefs JJHM (2010) Identification of a resistance gene Rpi-dlcl to Phytophthora infestans in European accessions of Solanum dulcamara. Theor Appl Genet 120:797-808

Goodwin SB, Sujkowski LS, Fry WE (1995) Rapid evolution of pathogenicity within clonal lineages of the potato late blight disease Fungus. J Phytopathol 85:669-676

Goodwin SB, Sujkowski LS, Fry WE (1996) Widespread distribution and probable origin of resistance to metalaxyl in clonal genotypes 
of Phytophthora infestans in the United States and Western Canada. J Phytopathol 86:793-800

Guo L, Zhu X, Hu C, Ristaino JB (2010) Genetic structure of Phytophthora infestans populations in China indicates multiple migration events. J Phytopathol 100:997-1006

Halpin C (2005) Gene stacking in transgenic plants-the challenge for 21st century plant biotechnology. Plant Biotechnol J 3:141-155

Harbaoui K, van der Lee Theo, Vleeshouwers VGAA, Khammassy N, Harrabi M, Hamada W (2013) Characterization of Phytophthora infestans isolates collected from potato and tomato crops in Tunisia during 2006-2008. Potato Res 56:11-29

Hein I, Birch PRJ, Danan S, Lefebvre V, Odeny DA, Gebhardt C, Trognitz F, Bryan GJ (2009) Progress in mapping and cloning qualitative and quantitative resistance against Phytophthora infestans in potato and its wild relatives. Potato Res 52:215-227

Huang S, van der Vossen EAG, Kuang H, Vleeshouwers VGAA, Zhang N, Borm TJA, van Eck HJ, Baker B, Jacobsen E, Visser RGF (2005) Comparative genomics enabled the isolation of the $R 3 a$ late blight resistance gene in potato. Plant $\mathrm{J} 42: 251-261$

Huibers RP, Loonen AEHM, Gao D, van der Ackerveken G, Visser RGF, Bai Y (2013) Powdery mildew resistance in tomato by impairment of SLPMR4 and SLDMR1. PLoS ONE 8(6):e67467

Hulbert SH, Webb CA, Smith SM, Sun Q (2001) Resistance gene complexes: evolution and utilization. Annu Rev Phytopathol 39:285-312

Jia Z, Cui Y, Li Y, Yang Y, Huang S, Du Y (2009) Expression the potato late blight resistant gene R3a, R1 and RB in tomato. Acta Hortic Sin 36:1153-1160 (in Chinese)

Jo K (2013) Unveiling and deploying durability of late blight resistance in potato: from natural stacking to cisgenic stacking. $\mathrm{PhD}$ thesis, Wageningen University, p 63-79

Jo K, Arens M, Kim T, Jongsma MA, Visser RGF, Jacobsen E, Vossen JH (2011) Mapping of the S. demissum late blight resistance gene $R 8$ to a new locus on chromosome IX. Theor Appl Genet 123:1331-1440

Jones J, Foster SJ, Chu Z, Park T, van der Vossen E, Andries G, Pel MA, Visser RGF (2009) Late blight resistance genes and methods. World Intellectual Property Organization, International Application No. PCT/GB2008/002469

Jørgensen JH (1992) Discovery, characterization and exploitation of MLO powdery mildew resistance in barley. Euphytica 63:141-152

Jupe F, Witek K, Verweij W, Śliwka J, Pritchard L, Etherington GJ, Maclean D, Cock PJ, Leggett RM, Bryan GJ, Cardle L, Hein I, Jones JDG (2013) Resistance gene enrichment sequencing (RenSeq) enables reannotation of the NB-LRR gene family from sequenced plant genomes and rapid mapping of resistance loci in segregating populations. Plant J 76:530-544

Kim MJ, Mutschler MA (2000) Differential response of resistant lines derived from the L. pimpinellifolium accession L3708 and L. hirsutum accession LA1033 against different isolates of Phythophthora infestans in detached leaf lab assays. Tomato Genet Coop Rep 50:23-25

Krattinger SG, Jordan D, Mace ES, Raghavan C, Luo MC, Keller B, Lagudah ES (2013) Recent emergence of the wheat Lr34 multi-pathogen resistance: insights from haplotype analysis in wheat, rice, sorghum and Aegilops tauschii. Theor Appl Genet 126:663-672

Lanfermeijier F, Dijkhuis J, Sturre M, Haan P, Hille J (2003) Cloning and characterization of the durable tomato mosaic virus resistance gene Tm- $2^{2}$ from Lycopersicon esculentum. Plant Mol Biol 52:1037-1049

Leister D (2004) Tandem and segmental gene duplication and recombination in the evolution of plant disease resistance genes. Trends Genet 20:116-122
Li G, Huang S, Guo X, Li Y, Yang Y, Guo Z, Kuang H, Rietman H, Bergervoet M, Vleeshouwers VGGA, van der Vossen EAG, Qu D, Visser RGF, Jacobsen E, Vossen JH (2011a) Cloning and characterization of $R 3 b$, members of the $R 3$ superfamily of late blight resistance genes show sequence and functional divergence. Mol Plant Microbe Interact 24:1132-1142

Li J, Liu L, Bai Y, Finkers R, Wang F, Du Y, Yang Y, Xie B, Visser RGF, van Heusden AW (2011b) Identification and mapping of quantitative resistance to late blight (Phytophthora infestans) in Solanum habrochaites LA1777. Euphytica 179:427-437

Li Y, van der Lee T, Zhu J, Jin G, Lan C, Zhu S, Zhang R, Liu B, Zhao Z, Kessel G, Huang S, Jacobesen E (2013) Population structure of Phytophthora infestans in China-geographic clusters and presence of the EU genotype Blue-13. Plant Pathol 62:932-942

Livak KJ, Schmittgen TD (2001) Analysis of relative gene expression data using real-time quantitative PCR and the $2^{-\Delta \Delta \mathrm{Ct}}$ method. Methods 25:402-408

Lough RC (2003) Inheritance of tomato late blight resistance in Lycopersicum hirsutum LA1033. North Carolina State University, Raleigh

McDowell JM, Simon SA (2006) Recent insights into $R$ gene evolution. Mol Plant Pathol 7:437-438

Merk HL, Foolad MR (2012) Parent-offspring correlation estimate of heritability for late blight resistance conferred by an accession of the tomato wild species Solanum pimpinellifolium. Plant Breeding 131:203-210

Merk HL, Ashrafi H, Foolad MR (2012) Selective genotyping to identify late blight resistance genes in an accession of the tomato wild species Solanum pimpinellifolium. Euphytica 187:63-75

Meyers BC, Kozik A, Griego A, Kuang H, Michelmore RW (2003) Genome-wide analysis of NBS-LRR-Encoding genes in Arabidopsis. Plant Cell 15:809-834

Michelmore RW, Meyers BC (1998) Clusters of resistance genes in plants evolve by divergent selection and a birth-and-death process. Genome Res 8:1113-1130

Michelmore RW, Christopoulou M, Caldwell KS (2013) Impacts of resistance gene genetics, function, and evolution on a durable future. Annu Rev Phytopathol 51:291-319

Moreau P, Thoquet P, Olivier J, Laterrot H, Grimsley N (1998) Genetic mapping of $P h-2$, a single locus controlling partial resistance to Phytophthora infestans in tomato. Mol Plant Microbe Interact 11:259-269

Nowicki M, Foolad MR, Nowakowska M, Kozik EU (2012) Potato and tomato late blight caused by Phytophthora infestans: an overview of pathology and resistance breeding. Plant Dis 96:4-17

Oyarzun PJ, Pozo A, Ordoñez ME, Doucett K, Forbes GA (1998) Host specificity of Phytophthora infestans on tomato and potato in Ecuador. J Phytopathol 88:265-271

Panthee DR, Gardner RG (2010) 'Mountain Merit': a late blight resistant large-fruited hybrid tomato. HortScience 45:1547-1548

Parniske M, Jones JDG (1999) Recombination between diverged clusters of the tomato $C f-9$ plant disease resistance gene family. Proc Natl Acad Sci USA 96:5850-5855

Parniske M, Hammond-Kosack KE, Golstein C, Thomas CM, Jones DA, Harrison K, Wulff BBH, Jones JDG (1997) Novel disease resistance specificities result from sequence exchange between tandemly repeated genes at the $\mathrm{Cf} 4 / 9$ locus of tomato. Cell 91:821-832

Peirce LC (1971) Linkage tests with $P h$ conditioning resistance to race 0 Phytophthora infestans. Tomato Genet Coop Rep 21:30

Pel MA (2010) Mapping, isolation and characterization of genes responsible for late blight resistance in potato. $\mathrm{PhD}$ thesis, Wageningen University, p 111-138

Pel MA, Foster SJ, Park T, Rietman H, van Arkel G, Jones JDG, van Eck H, Jacobsen E, Visser R, van der Vossen EAG (2009) Mapping and cloning of late blight resistance genes from Solanum 
venturii using an interspecific candidate gene approach. Mol Plant Microbe Interact 22:601-615

Rich AE, Richards MC, Meader EM (1962) Rockingham, a new tomato variety resistant to late blight. Plant Dis Rep 46:130

Robbins MD, Masud MA, Panthee DR, Gardner RG, Francis DM, Stevens MR (2010) Marker-assisted selection for coupling phase resistance to Tomato spotted wilt virus and Phytophthora infestans (late blight) in tomato. HortScience 45:1424-1428

Rodewald J, Trognitz B (2013) Solanum resistance genes against Phytophthora infestans and their corresponding avirulence genes. Mol Plant Pathol 14:740-757

Smart CD, Tanksley SD, Mayton H, Fry WE (2007) Resistance to Phytophthora infestans in Lycopersicon pennellii. Plant Dis 91:1045-1049

Smilde WD, Brigneti G, Jagger L, Perkins S, Jones JDG (2005) Solanum mochiquense chromosome IX carries a novel late blight resistance gene Rpi-moc1. Theor Appl Genet 110:252-258

Statsyuk NV, Kuznetsova MA, Kozlovskaya IN, Kozlovsky BE, Elansky SN, Morozova EV, Valeva EV, Filippov AV (2010) Characteristics of the Phytophthora infestans population in Russia. PPO Spec Rep 14:247-254

The Tomato Genome Consortium (2012) The tomato genome sequence provides insights into fleshy fruit evolution. Nature 485:635-641

Thomas CM, Jones DA, Parniske M, Harrison K, Balint-Kurti PJ, Hatzixanthis K, Jones JDG (1997) Characterization of the tomato Cf-4 gene for resistance to Cladosporium fulvum indentifies sequences that determine recognitional specificity in Cf-4 and Cf-9. Plant Cell 9:2209-2224

van der Biezen EA, Jones JDG (1998) The NB-ARC domain: a novel signalling motif shared by plant resistance gene products and regulators of cell death in animals. Curr Biol 8:R226-R228

van der Voort JR, Kanyuka K, van der Vossen E, Bendahmane A, Mooijman P, Klein-Lankhorst R, Stiekema W, Baulcombe D, Bakker J (1999) Tight physical linkage of the nematode resistance gene Gpa2 and the virus resistance gene $R x$ on a single segment introgressed from the wild species Solanum tuberosum subsp. Andigena CPC 1673 into cultivated potato. Mol Plant Microbe Interact 12:197-206

van der Vossen E, Sikkema A, Hekkert Bt, Gros J, Stevens P, Muskens M, Wouters D, Pereira A, Stiekema W, Allefs S (2003) An ancient $R$ gene from the wild potato species Solanum bulbocastanum confers broad-spectrum resistance to Phytophthora infestans in cultivated potato and tomato. Plant J 36:867-882 van der Vossen EAG, Gros J, Sikkema A, Muskens M, Wouters D, Wolters P, Pereira A, Allefs S (2005) The Rpi-blb2 gene from Solanum bulbocastanum is an Mi-1 gene homolog conferring broad-spectrum late blight resistance in potato. Plant $\mathrm{J}$ 44:208-222

van Ooijen G, van den Burg HA, Cornelissen BJC, Takken FLW (2007) Structure and function of resistance proteins in Solanaceous plants. Annu Rev Phytopathol 45:43-72

Vega-Sánchez ME, Erselius LJ, Rodriguez AM, Bastidas O, Hohl HR, Ojiambo PS, Mukalazi J, Vermeulen T, Fry WE, Forbes GA (2000) Host adaptation to potato and tomato within the US-1 clonal lineage of Phytophthora infestans in Uganda and Kenya. Plant Pathol 49:531-539

Verzaux (2010) Resistance and susceptibility to late blight in Solanum: gene mapping, cloning and stacking. $\mathrm{PhD}$ thesis, Wageningen University, p 57-80

Vleeshouwers VGAA, van Dooijeweert W, Keizer LCP, Sijpkes L, Govers F, Colon LT (1999) A laboratory assay for Phytophthora infestans resistance in various Solanum species reflects the field situation. Eur J Plant Pathol 105:241-250

Vleeshouwers VGAA, Rietman H, Krenek P, Champouret N, Young C, Oh S, Wang M, Bouwmeester K, Vosman B, Visser RGF, Jacobsen E, Govers F, Kamoun S, van der Vossen EAG (2008) Effector genomics accelerates discovery and functional profiling of potato disease resistance and Phytophthora infestans avirulence genes. PLoS ONE 3:e2875

Vleeshouwers VGAA, Raffaele S, Vossen JH, Champouret N, Oliva R, Segretin ME, Rietman H, Cano LM, Lokossou A, Kessel G, Pel MA, Kamoun S (2011) Understanding and exploiting late blight resistance in the age of effectors. Annu Rev Phytopathol 49:507-531

Zhang C, Liu L, Zheng Z, Sun Y, Zhou L, Yang Y, Cheng F, Zhang Z, Wang X, Huang S, Xie B, Du Y, Bai Y, Li J (2013) Fine mapping of the $P h-3$ gene conferring resistance to late blight (Phytophthora infestans) in tomato. Theor Appl Genet 126:2643-2653

Zhu S, Li Y, Vossen J, Visser RGF, Jacobsen E (2012) Functional stacking of three resistance genes against Phytophthora infestans in potato. Transgenic Res 21:89-99

Zhu S, Duwal A, Su Q, Vossen J, Visser RGF, Jacobsen E (2013) Vector integration in triple $R$ gene transformants and the clustered inheritance of resistance against potato late blight. Transgenic Res 22:315-325 